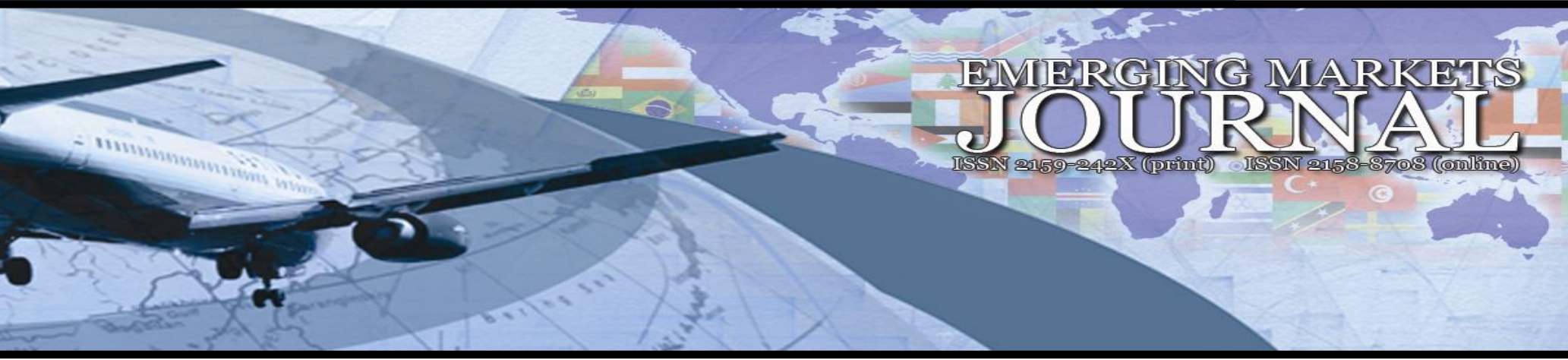

\title{
Auditing Techniques to Minimize Accounting Related Fraud and Errors: A Qualitative Analysis with the Interview Method
}

\section{Cevdet Kizıl}

Istanbul Medeniyet University, Turkey | e-mail: cevdetkizil@yahoo.com

\section{Erol Muzir}

Istanbul Medeniyet University, Turkey | e-mail: erol.muzir@ medeniyet.edu.tr

\section{Vildan Yılmaz}

Certified Public Accountant (CPA) and Independent Researcher, Turkey | e-mail: vildanbrt77@gmail.com

$$
\text { Volume } 11 \text { No } 1 \text { (2021) ｜ＩSSN 2158-8708 (online) ｜ DOI 10.5195/emaj.2021.232 | http://emaj.pitt.edu }
$$

\begin{abstract}
Accounting is more integrated with the technology today compared to the previous years. The increase in a variety of technological developments and commercial transactions has further increased the number and type of errors as well as frauds related to the accounting profession. This causes misleading information for several stakeholders. Stakeholdes sometimes make false decisions based on the financial statements created as a result of false and fraudulent transactions. In order to minimize the errors and frauds concerning the accounting system of enterprises, effective internal controls and auditing systems should be in order. It is evident that, setting up the required internal controls and auditing systems reduce asset losses and provide great benefits in the long run for firms. Existence of strong internal controls and auditing systems in enterprises has gained great importance in Turkey. This study provides information about the audit techniques that can minimize accounting related frauds and errors in businesses. The research includes and employs an interview with auditing professionals as the research methodology. Auditors working within three audit firms were selected by simple random sampling via the LinkedIn social media. The three participants were directed 10 semi- structured and open-ended questions. Qualitative analysis was adopted for this study. According to the results of research, companies use a number of tools to prevent accounting related frauds and errors. These most effective tools to minimize the frauds and errors are detected as internal auditing, internal controls and independent (external) auditing. Auditing professionals have high awareness about accounting related fraud and errors. But, auditor independency should be higher, proactive approach must be utilized and auditors must closely follow the new laws and regulations in addition to being familiar with the firms's operations and sectors to minimize the fraud and errors. The Benford's law, artificial neural networks, analytical methods, data mining, red flags and analytical methods are commonly used by the auditors against frauds and errors. In general, the internal controls and auditing professions are in a much better situation today in Turkey compared to the previous years. But, this is still not adequate and there is a long way to complete ahead based on the opinions of auditing professionals.
\end{abstract}

Keywords: Accounting, Auditing, Internal Controls, Fraud, Error

\section{$(\mathrm{cc}) \mathrm{Br}$}

New articles in this journal are licensed under a Creative Commons Attribution 3.0 United States License.
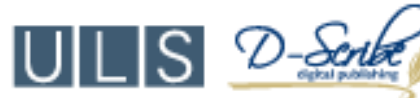

This journal is published by the University Library System of the University of Pittsburgh as part of its D-Scribe Digital Publishing Program, and is cosponsored by the University of Pittsburgh Press. 


\section{Auditing Techniques to Minimize Accounting Related Fraud and Errors: A Qualitative Analysis with the Interview Method}

\author{
Cevdet Kızıl \\ Erol Muzir \\ Vildan Yılmaz
}

\section{Introduction}

The continual change of economic conditions in the world, the increasing competition among businesses and the rapid development of information technologies have started to affect the businesses both in positive and negative directions. As operation volumes of businesses grew, firms began to become more complicated with records of accounting system due to increased transactions. This complexity has also made it more difficult for businesses to control financial transactions, while also creating appropriate environments for fraudulent transactions (Dönmez and Çavuşoğlu, 2015).

Financial statements should present financial information that is reliable, understandable, comparable and appropriate for the users of financial statements. Financial statements bearing these characteristics are obtained through the integration of internal controls, auditing and corporate governance elements. This definitely creates a reliable financial reporting environment. However, there have been some accounting scandals that are echoing in the world with transactions and records that are contrary to accounting and financial reporting principles (Atmaca, 2012).

Since the second half of the XX. century, businesses have not succeeded in fighting with this complicated economic and financial structure, and many corporate fraudulent scandals such as Enron, WorldCom and Parmalat have come to the scene (Kızıl and Kaşbaş1, 2018; Kizıl et. al. 2016). Emergence of neglect of accounting and auditing firms in these large corporate frauds has increased awareness on the financial sector and regulatory agencies side. There has been a perception that auditing profession and auditors have failed to detect the frailty and are not diligent enough to detect and prevent fraud in the society. These scandals have forced the redefinition of the responsibilities of auditors and accountants for the detection of frauds in their organizations (Karausta and Dönmez, 2013).

One of the biggest problems faced by businesses is errors and frauds in the accounting system. Error and frauds are different concepts. Various definitions have been made about the fraud in scientific literature. Fraud is intentional. Also, it is sometimes the incorrect and incomplete misrepresentation of information about assets in the business, which do not reflect the reality of financial statements (Kaval, 2005).
In other words, fraud is the intentional while an accounting error is unintentional (Söyler, 2013; Aslan, Kizıl and Din, 2017).

Fraud is also irregularities such as dishonesty, corruption and deliberate mistakes. Concerning the business person, individual in charge of the management or the third person is in deceptive behavior in order to gain consciously interests (Güredin, 2007). Any arrangement that one person will benefit from another person is within the scope of fraud. Some of them constitute unjust acquisition of assets, bribery, fraudulent documents and reports, embezzlement, theft, expense and cost inflation as well as unfair use of business assets. These unfair revenues may be obtained by direct acquisition of the owner's money or goods, as well as by indirect means such as rewarding, receiving bonuses or providing power (Bozkurt, 2000).

In order to better understand the concept of fraud, we can list the following issues: Fraud is an activity that is secretly carried out by cheaters. The scammer has the principle of benefiting himself / herself from the fraud action. There is absolutely intentional content, which means that the victim is deceived in some way and the individual or business subject to fraud is hurt by the action in every case (Bozkurt, 2009).

An accounting error is a mistake in the process of systematically recording, categorizing, summarizing and reporting information about financial transactions. In accounting errors, there is no intention. But, there is ignorance and negligence. For example, if a machine or equipment that had to be recorded under fixed assets was recorded as general administrative expenses unintentionally, then this is an accounting error. Thus, accounting errors generally result from lack of information or personal carelessness about accounting principles and standards (Kara, 2012). Errors also arise when an asset is not recorded in the book. In cases where assets are recorded in different accounting periods, they are recorded with wrong sums, or recorded under a wrong account, debt or receivable. There are differences in the classification of accounting errors. Math and calculation mistakes, recording mistakes, forgotten and recurring account mistakes, transferring mistakes, balance errors and remedial mistakes can be listed at this point (Özer, 1998).

Thus, the main distinction between error and fraud is intention. The missteps are deliberately and deliberately carried out in the fraud while accounting mistakes come into play due to unintentional reasons due to ignorance and carelessness. While accounting errors are usually limited to records, accounting frauds are made on both the records and documents intended to hide false records. It is much more difficult to detect and prove frauds than mistakes, while it is easier to uncover and correct mistakes because there is no intention.

It is necessary to know the causes, types and environments that help to cheat in order to take preventative steps for fraud and in order to reveal the scam. The Association of Certified Fraud Examiners (ACFE) classifies fraud as follows (Kirac1, 2013): 
Table 1: Classification of Fraud

\begin{tabular}{|c|c|c|c|c|}
\hline CORRUPTION & \multicolumn{2}{|c|}{ ABUSE OF ASSETS } & \multicolumn{2}{|c|}{$\begin{array}{c}\text { FINANCIAL STATEMENTS } \\
\text { FRAUD }\end{array}$} \\
\hline $\begin{array}{c}\text { Conflict of } \\
\text { interest }\end{array}$ & Cash & $\begin{array}{c}\text { Related to } \\
\text { inventoty and } \\
\text { other assets }\end{array}$ & $\begin{array}{c}\text { Showing assets } \\
\text { /revenues } \\
\text { more than } \\
\text { actual sums }\end{array}$ & $\begin{array}{c}\text { Showing assets } \\
\text { / revenues less } \\
\text { than actual } \\
\text { sums }\end{array}$ \\
\cline { 1 - 3 } Bribe & Stealing money & Abuse & \\
\hline Illegal tip & $\begin{array}{c}\text { Stealing cash } \\
\text { voucher }\end{array}$ & $\begin{array}{c}\text { Inventory } \\
\text { theft }\end{array}$ & & \\
\hline Tribute & $\begin{array}{c}\text { Fraudulent } \\
\text { payment }\end{array}$ & & \\
\hline
\end{tabular}

Resource: Kirac1, M. (2013). Hileye Yönelik Uluslararası Kuruluşların Hazırladığı Raporların Bağımsız Denetim Açısından Değerlendirilmesi. Muhasebe ve Vergi Uygulamaları Dergisi, Cilt: 6, Sayı: $3,87-106$.

According to Terzi, fraud is categorized in two. These are the frauds committed by management and the frauds commited by employees as it is observed in Figure 1 below (Terzi, 2012).

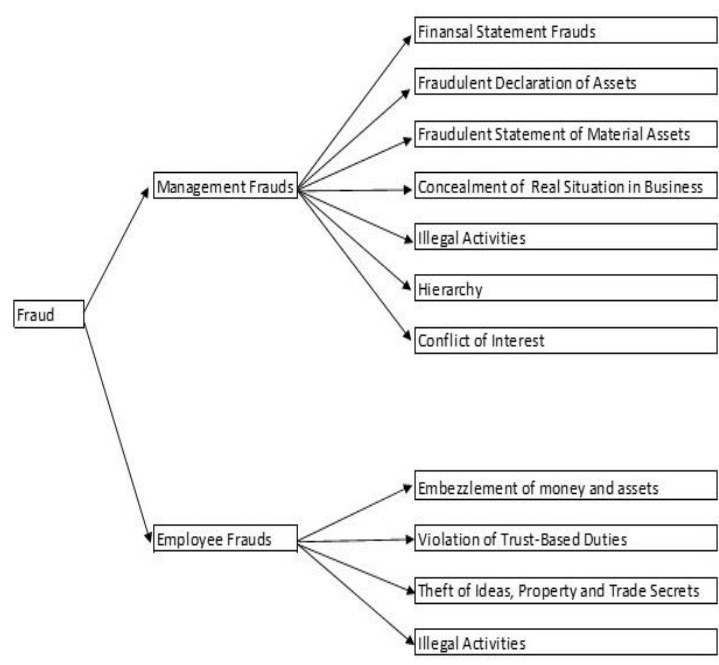

Figure 1. Types of Fraud

Resource: Terzi, S. (2012). Hile ve Usulsüzlüklerin Tespitinde Veri Madenciliğinin Kullanimi. Muhasebe ve Finansman Dergisi, Say1: 54, 51-64.

Frauds created by employees arise due to factors in elements of repression seen in the fraud triangle. Some of these scams are listed below (Pazarçeviren, 2005):

- Employees transferring money to their accounts without reflecting them in the records

- Gaining monetary benefit by playing with bank records on which they relate

- Providing payments by creating unrealistic debts and fraudsters in favor of business

- Burglary through items such as office materials, fixed assets and stock

- Personal use of business assets and firm credit cards
- Bribery of business customers or suppliers for various reasons

- Providing benefits with inflated personal health or travel expenses

- Overpayments

Examples of management tricks in terms of fraud can be indicated as follows (Pazarçeviren, 2005):

-Recording non-real income items (e.g., generating income by changing similar valued assets between businesses and increasing the income by making false predictions in the interim financial statements)

- Increasing revenue with one-time gains (e.g., selling a low-valued assets at high values and paying debts earlier unnecessarily to provide discounted revenues)

- Transferring the current period expenses to the next term

- Recording future period expenses as current turnover expenses

The fraud triangle is indicated below in Figure 2 (Morales, Gendron and Guenin-Paracini, 2014):

\section{Fraud Triangle}

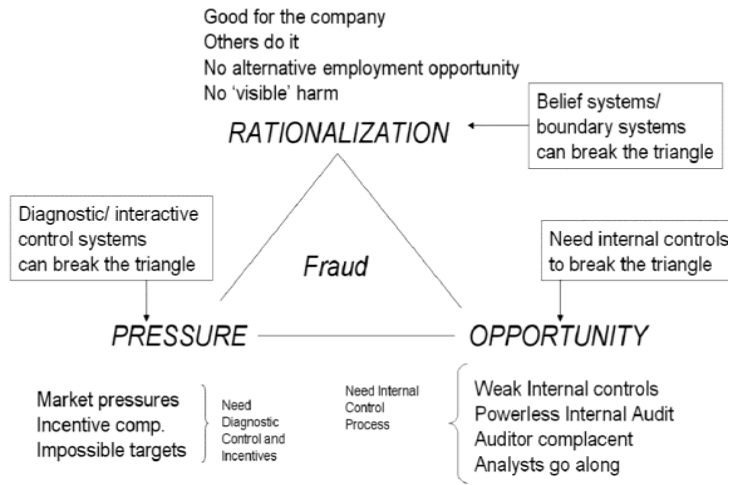

Figure 2. Fraud Triangle

Resource: Morales, J., Gendron, Y. and Guenin-Paracini, H. (2014). The Construction of the Risky Individual and Vigilant Organization: A Genealogy of the Fraud Triangle. Accounting, Organizations and Society. Vol. 39, Issue: 3, 170-194.

The abuse of assets is rarely achieved by the business management. However, management can easily overcome powers and controls, thus enabling to hide frauds well. So, amount of embezzlement can reach to very significant and serious sums. According to the literature, although the number of corruption such as embezzlement and bribery by the top management personnel is low by quantity and numbers, sums are about three times higher than total sum of corruption incurred by other employees (Güredin, 2007). When the elements of fraud triangle are compared to fire, gasoline and oxygen, it is likely that there will be a fire and explosion when these elements come together. Here, fraud action will not be easy unless the three elements in the fraud triangle come together. Concerning the pressure, generally managers want the financial results and indicators to look good. This is because good 
financial resultes and indicators are reflected to their wages, premiums and bonus. This kind of pressure can create falsification of accounting information and result in improper reflection of financial reports. Gambling debts of some employees, credit card debts and money requirements arising from various reasons in the business do also cause employees and managers to resort to fraudulent ways by creating pressure (Erdoğan, 2006).

Besides, opportunity is the absence of an internal controls system in business or lack of efficiency in the internal controls system. This may apply to any employee's fraudulent operation, which takes advantage of the opportunity. However, an effective internal controls system that exists in the business limits the opportunity of fraudulent transactions (Ramos, 2003). On the opposite side, employees or managers who are aware of internal controls gaps in the firm's system can take what they want without too much effort (Emir, 2008). In regards to rationalization, the company tends to honestly justify itself as a reason for executives and employees to manipulate their own conscience. For example, in case of embezzlement, executives and employees relieve their conscience by borrowing money to justify themselves (Bulca, 2014).

In the scope of this study, firstly the definition of fraud and accounting error were provided. Then, the internal controls and auditing techniques were also mentioned. In this context, the study started with the introduction section. Then follows the Literature Review, Data and Methodology, Research Findings and Conclusion and Recommendation sections.

\section{Literature Review}

Although research on audit techniques that can prevent fraud and accounting errors are still limited, they are constantly increasing. Studies in this field contribute to the literature in the recent years (Aksoy and Uzay, 2021; Akman, Acar and K1zıl, 2020; Adalı and Kızıl, 2017; Kirac1, 2013; Şengür, 2011; ACFE, 2010; Kandemir, 2010; Çubukçu, 2009; ACFE, 2008; Kula, 2008; PWC, 2007 and Bayraktar, 2007). Some of the research conducted are theoretical studies related to the forensic accounting science and auditing, while others are empirical studies. It should be noted that, studies analyzing fraud in the Covid-19 era do also currently attact attention in the related literature (Jamil et. al., 2021; Widiyati et. al., 2021; Kız1l, Muzır and Akman, 2021).

Accounting frauds arise on grounds that resources or assets are shown intentionally and incorrectly on wrong accounts. In this case, wrong and tricky financial statements are prepared with aim of providing benefit to specific individuals or institutions (Kula, 2008). In order for an accounting fraud to be possible, it needs to have two components: Firstly, the situation that is valid for accounting errors should have full intention. In other words, fraud is deliberately misleading, unlike error. Cheating people either deliberately deceive other side, or misrepresent facts and push other side to make misrepresentation. In order for a mistake to be intentional, two conditions must exist. The person who commits fraud should be aware of the mistake made and he/she should know that other parties believe in financial statements and will report these misleading statements if they recognize the situation. Secondly, employees or managers in the business should act and behave in order to receive benefits. The fact that people are acting on basis of their interests is already a deliberate initiative. Fraud for personal interests damages the business for sure (Çubukçu, 2009).

Some field surveys were conducted to determine the proportional status of these fraud types. One of the most important studies showing ratios of fraud types were run by the American Certified Fraud Examiners (ACFE). According to ACFE's survey of businesses in 2006 and 2008 , they had distinguished fraud types as abuse of assets, corruption and fraudulent financial reports. According to the results of research, it is seen that the ratio of the frauds in the financial statements of enterprises is the lowest one. In ACFE's research in 2008, the frequency of abuse of assets was $88,7 \%$. The cost of this ratio was about 150.000 United States (U.S.) dollars (ACFE, 2008). According to the survey conducted in 2010 , abuse of assets had $86,3 \%$, unfair profit had $32,8 \%$ and fraudulent financial statements had $4,8 \%$ ratio. The average cost of these ratios were 4,1 million U.S. dollars in misappropriation of assets, 250,000 U.S. dollars in unfair earnings and 135,000 U.S. dollars in fraudulent financial statements (ACFE, 2010).

According to the survey conducted by PricewaterhouseCoopers (PWC) in 2007 at Turkey, intellectual property theft cases were observed with a ratio of $14 \%$ and accounting fraud and unfair acquisitionbribery cases were observed with a ratio of $8 \%$. The abuse of assets were observed with a ratio of $19 \%$. When we have a look at the studies on the tools used by businesses in the absence of salaries, it is seen that findings in the literature are parallel (PWC, 2007).

In a research conducted in 2013, it was mentioned that auditors who are affiliated to the Capital Markets Board (CMB) are more likely to assist internal auditors, conduct audits, obtain information about management and share possible fraud information for effective independent (external) auditing. Moreover, according to research results, risk assessment is very important. Independent (external) auditing has created a great deal of confidence in the prevention of fraud, errors and deceptions in business. Also, revision of existing legal regimes in Turkey reached to a conclusion that, existing laws and regulations had to be reconsidered (Kirac1, 2013).

There are several studies published related to the fraud and accounting errors in Turkey. One of these studies dated 2011 distributed questionnaires to independent (external) and internal auditors to determine the most frequently detected types of fraud. The research also tried to determine the opinions of independent (external) and internal auditors on effectiveness of factors that prevented frauds. These are the effectiveness of the audit committee, pariticpation of a certified fraud supervisor joining the internal or independent (external) audit team, impementation of ethical rules and existence of a positive working environment (Şengür, 2011).

Another study conducted in 2007 discussed the history of fraud. The recent events and scandals have led to discussions related to the auditing and accounting fields based on this research. While accounting professionals develop their own methods, a number of techniques and methods have been developed to prevent and reveal deceptions made on other side. In order to apply these techniques and methods well, it has been 
pointed out that, the most frequently encountered manipulation paths should be investigated and grasped. In this study, causes and methods applied to frauds were examined by analyzing the scandals that took place in Turkey. It was also mentioned how important accounting is in today's business world. Definition, reasons, methods and techniques of the accounting scams were explained in detail together with the accounting scandals that took place in the world. This research mostly focused on illegal concepts such as accounting scams, use of false documents, corruption and tax evasion. As a result, it was determined in the study that between 1990 and 2007, the main aim of accounting frauds in Turkey was to hide actual occuring taxes and generating income in terms of corruption (Bayraktar, 2007).

Based on another research conducted in 2010, three general factors listed as internal auditing, internal controls and independent (external) auditing were indicated to be critical for eliminating accounting related fraud and errors. Also, the abuse of assets and fraudulent financial statements cause unfair business mergers and acquisitions. Thus, auditing and internal control systems are significant for the welfare of society (Kandemir, 2010).

\section{Data and Methodology}

The aim of this study was to emphasize the role of auditing in preventing accounting related frauds and errors in Turkey. Another purpose of the research was to determine whether these audits were carried out effectively by auditing professionals. Within the framework of auditor's opinions, scope of investigation includes problems encountered during auditing. Special considerations that auditors should pay attention to and requirements for better overall auditing were mentioned as well.

In this study, the interview technique was used as a qualitative research method. The main purpose of using an interview technique was to identify auditing professionals' experiences and present how they exceled with the mentioned experiences. The sample of study consists of auditing professionals employed in three audit firms selected through simple random sampling via the LinkedIn social media. The three participants were directed 10 semi- structured and open-ended questions. Information on interviewees and interview questions are provided in Table 2 below:
Table 2: Participant Information and Interview Questions

\begin{tabular}{|l|l|}
\hline Participants & Title of Participants \\
\hline Participant 1 (P1) & Auditor \\
\hline Participant 2 (P2) & Chairman of the Board of Directors, Auditor \\
\hline Participant 3 (P3) & Chairman of the Board of Directors, Auditor \\
\hline & Interview Questions \\
\hline & \\
1. Are you aware of accounting related fraud and errors in the world and Turkey? \\
2. Which auditing techniques should be implemented by employees and the management \\
of a business to protect from accounting related fraud and errors? \\
3. Do you proactively work as an auditor in the prevention of accounting related fraud and \\
errors? \\
4. Have you experienced an accounting related fraud or an error case in your professional \\
career? \\
5. Could you describe the potential cheater profile as an auditor? \\
6. What kind of approach do you use while supervising business activities? \\
7. What sort of order should be followed in terms of methods according to the degree of \\
importance in revealing fraud, corruption and errors in the company? \\
8. What are the challenges that supervisors may encounter when conducting a fraud or \\
error audit, or what should they pay attention to? \\
9. What do you think about accounting related fraud and error controls in Turkey? \\
10. How do you see the future of accounting related fraud and error controls in the world \\
and Turkey?
\end{tabular}

\section{Research Findings}

The research findings are indicated below in consequence as interview questions directed to auditing professionals (P1), (P2) and (P3) and their related responses for each question:

Question 1: Are you aware of accounting related fraud and errors in the world and Turkey?

According to the responses of participants, they are all informed about accounting related fraud and errors through the press and media. They are also informed by professional non-governmental organizations on the basis of distributed information. These apply for all the auditors (P1), (P2) and (P3) who are subject to this research.

Question 2: Which auditing techniques should be implemented by employees and the management of a business to protect from accounting related fraud and errors?

Above all, knowledge of professional legislation and technical application must be obtained. Then, actual independence is a must for sure. A couple of things can also be said under the name of audit technique, but I think that is not meaningful. Auditing is auditing, so I do not believe that this makes sense. Is audited transactions correct? Are internal and official legislations appropriate? Who are beneficiaries? Is utilization status legal? The format, methods and content are all important here. Internal controls is more significant and indispensable (P1).

Classical method and proactive method can be used. The classical method is a passive approach that is used to expose fraud and irregularities in traditional auditing techniques. The passive approach refers to the investigation of fraud and corruption in the context of traditional auditing. That is only examining financial items or situations that are under suspicion, making this when it is only needed or reported. The proactive method is contrary to the passive approach. This is any claim 
about fraud and corruption is an audit activity that adds account to the possibility of fraud and irregularities at all times without request or notice. In this method, as in the case of classical method, sampling is not enough and information technology (IT) enables the auditor to examine the whole database comfortably without any time cost (P2).

It is a fact about what measures should be taken to prevent abuse in these matters. Criteria and risks should be assessed, risk planning and deterrent measures should be taken considering the opinions and practices of a professsional, who is at least as knowledgeable as the person commiting fraud. It is essential to know and learn to think exactly like a cheater to solve the abuse (P3).

Question 3: Do you proactively work as an auditor in the prevention of accounting related fraud and errors?

Yes. All new applications and implementations in operation are subject to review by the audit department. Regulations and technical instructions sometimes change related to work patterns. Active participation in work though the processes is a must (P1), (P2), (P3).

Question 4: Have you experienced an accounting related fraud or an error case in your professional career?

I experienced several accounting related fraud and error cases in my professional career (P1). So far, I have been involved in a lot of accounting related fraud and error cases in a total of 6 sectors (P2). I have completed the investigation of numereous accounting related fraud and error events through my professional career (P3).

Question 5: Could you describe the potential cheater profile as an auditor?

Those who tend to spend more than their income, are excessively involved in bet games and stock exchange transactions, have weak family ties, believe they have been treated unfairly for a long time, have resentment against the business, have family or friends who have serious health problems, need money urgently, have excessive debts, can emotionally and easily influenced by other's suggestions, have low selfconfidence are potential cheater profiles in my opinion (P1). Potential cheaters are artificial individuals who try to reflect that they are always sincere, well-dressed and intelligent. They always try to influence others with their unrealistic characteristics (P2). Fraud staff can be confronted at any stage. From leakage of money to using a double receipt, there are many types of fraud. So, it is very difficult to describe a definite profile in my opinion. It would also be dangerours to come up with such a generalization. I somtimes even observe people who cheat despite their high level of education and social status (P3).

Question 6: What kind of approach do you use while supervising business activities?

I will exhibit an objective (neutral, equal distance) approach. Then I will take an approach that puts everything under supervision, assuming that every individual can cheat and gain an unfair advantage (Starting from the owners of business to all the senior executives and ordinary employees). I would like to determine the scope and depth of audit by my side. (P1). The method we use most proactively is actually personalized and unique according to the nature of auditor and company profile (P2). To speak honestly, I always follow the theoretical developments and publications related to my profession. I believe that constantly reading and making research is very important in our job. Then, I always try to blend these with my practical knowledge and experience in the field (P3).

Question 7: What sort of order should be followed in terms of methods according to the degree of importance in revealing fraud, corruption and errors in the company?

I place importance on operations of the company according to the degree of influence on market. Legal obligations of the firm are also important. I inspect transactions in order of importance within the time period for audit (P1). There are a lot of methods that I have to consider (P2). Today, many control elements such as fraud policies, fraud risk appraisal, duty rotation and training to protect against fraud and errors have been developed in order to prevent asset losses in the business. Several methods have been used to detect frauds and errors, such as the Benford's law, artificial neural networks, analytical methods, data mining, red flags and analytical methods (P3).

Question 8: What are the challenges that supervisors may encounter when conducting a fraud or error audit, or what should they pay attention to?

Suggestions and guidance of others must be considered. However, restrictions on the scope of audit must definitely be eliminated. Also, sometimes there is pressure from auditees and top managers that auditors are dependent on. That has to change, because this is currently one of the biggest problems for Turkey in the auditing profession (P1). Documents and records need to be examined may be inadequate or partially hidden. The documents and records submitted must be tested for authenticity. This does not have a standard. Testing of accuracy for each document and record is different from receiving confirmation from the interested parties (P2). Independent auditor should use his/her professional judgment to decide which technique he/she should choose, and at what level they will be used. Expectations of the top management should be considered by the auditor as well. The main aim of any business is to make profit. The auditor should know the company well and must be familiar with the operations as well as the sector of business. He/she should also make sure that, transactions are carried out in accordance with the procedures determined by authorities $(\mathrm{P} 3)$.

Question 9: What do you think about accounting related fraud and error controls in Turkey?

Accounting related fraud and error controls are more effective in Turkey compared to the previous years. Fraud and error inspections are very effective in high scaled international companies in Turkey. Importance to

Auditing Techniques to Minimize Accounting Related Fraud and Errors: A Qualitative Analysis with the Interview Method 
accounting related fraud and error controls is given much more now and the awareness is higher. The required time and staff to minimize the accounting related fraud and error are generally determined correct as well (P1). Internal auditing, fraud and error supervision are still not very effective and more improvements are needed. First of all, internal auditors are sometimes regarded as an expense factor and some firm oweners as well as top managers consider them to to be inefficient from the beginning. This is a very dangerous and biased approach, which also hurts the Turkish economy. Thus, internal auditors are not financially supported in specific companies from the beginning. In some situations, an internal auditor is just employed because of the law or considering the reputation of firm against other organizations. Subjective preferences of the business owner or top managers, rather than the recommendations and suggestions of the internal auditor also cause significant problems. Internal auditing is still not seen as a separate field of expertise in some companies (P2). I believe that controls to prevent the accounting related fraud and errors heve developed significantly in the recent years at Turkey. We are definitely not the best and still have a long jouney to complete, but the latest improvements make me pleased. I am much more hopeful for the future. Professionals even in the large scaled and famous firms had not heard of internal controls and auditing in the former years at Turkey. However, we can even observe middle sized firms with separate auditing, internal controls and risk management departments today (P3).

\section{Question 10: How do you see the future of accounting related fraud and error controls in the world and Turkey?}

Accounting related fraud and error auditing in the world and Turkey is becoming increasingly important. Whether or not the losses caused by fraudulent institutions can be foreseen, this increases awareness (P1). Accounting related fraud and error auditing will become even more important in the future. Especially the population growth, increase in unemployment, inequality in income distribution, higher competition, moral collapse and worsening of value judgments will increase in the following years in my opinion. Thus, accounting related fraud and error auditing will be more critical. Institutions will also necessarily have to give more importance to set up sound internal control systems (P2). The concept of accounting related fraud and error auditing in Turkey has not evolved completely. Institutional ownership as well as emotions and preferences of company owners/top managers give rise to this situation. Firms will also have some unpleaseant experiences in this time interval. However, "A misfortune is better than thousand advices". Overall, awareness of auditing and internal controls will increase more by time (P3).

\section{Conclusion and Recommendations}

Employee and mangement frauds as well as errors, which has become an institutional problem, can be avoided by proactive practices that can be developed in parallel with technological improvements. The recent issues have increased the responsibilities of auditos as well as the scope of their authority. Accounting related fraud and error auditing is gaining importance day by day due to financial scandals experienced around world. The mentioned scandals are observed frequently in the recent years and even some giant enterprises went to bankruptcy because of them.

According to the results of this study, economic impact of accounting related fraud and errors is quite serious. All businesses must have strong backgrounds in terms of internal controls and auditing. Following the codes of ethics also helps the reduction of accounting related fraud errors. Timely measures and actions are important at this point.

In this research, responsibilities of the auditors who are in charge of frauds and errors were closely examined. As a result of in-depth interviews carried out in this context, it was revealed that knowledge of professional legislation and technical practices were cirtical. Absolutely, independence is an eye-catching factor as well. Both the classical and proactive methods can be used to minimize accounting related fraud and errors. Although the proactive method is widely preferred, it is not always completely enough because of the sampling techqniue instead of handling the whole universe. The usage of information technologies is a must for auditors in today's business world in terms of time, workload and cost savings.

Data included in financial statements prepared by the business must be delivered to interested parties in a timely, accurate, reliable, understandable, complete, comparable and up-to-date manner. Independent (external) auditors are needed to meet this purpose and increase investor confidence in the financial information. Independent (external) auditors are obliged to submit an opinion to express whether the financial information reported by the business is prepared in accordance with the generally accepted accounting principles (GAAPs).

In order to be able to take action against accounting related fraud and errors in both the public and private sectors, each institution should pay attention to specific issues. The proactive fraud audit approach requires the use of preventive and detective methods. There might always be a fraud within the institution. Attempting to examine the accounting related fraud or error when there is a notice or suspicion is a passive approach and would not always work. The fraud environment is like a virus. A virus can be more effective on the human body if it is weak. But, this will not be the case when the human body is strong. Likewise, the accounting related fraud or error can not be observed in the company, at least in high ratios, without finding and detecting a suitable environment. It is also useful to pay attention to the issues, which prepare a ground for the fraud and error environment such as unfairness, not paying attention to transparency, weakness of company's internal controls and auditing systems, excessive trust in individuals and not establishing an atmosphere of accountability.

Finally, the easiest way to reduce the accounting related fraud and errors in businesses is to concentrate on preventive steps and methods, rather than trying to detect fraud and errors. That is why the internal controls system is as important as the auditing system. Therefore, it is important to operate an effective and continuously renewable internal controls system in addition to an ideal auditing system. All these will reduce errors, accounting related fraud, asset losses, wastes and corruptions in the company. At the same time, accurate financial reporting should be ensured in a correct and reliable manner, which 
will also increase the productivity. The interviews conducted with auditing professionals as a qualitative research method provide the significance of all these issues and shed light to the future of auditing profession.

\section{References}

ACFE. (2008). ACFE 2008 Report to the Nation on Occupational Fraud\&Abuse. ACFE Website. https://www.acfe.com/uploadedFiles/ACFE_W ebsite/Content/documents/2008-rttn.pdf (Retrieved on 01.06.2021).

ACFE. (2010). ACFE 2010 Report to the Nation on Occupational Fraud\&Abuse - European Edition. ACFE Website. https://www.acfe.com/uploadedFiles/ACFE_W ebsite/ Content/documents/rttn-european.pdf (Retrieved on 02.02.2021).

Adal1, S., Kizıl, C. (2017). A Research on the Responbility of Accounting Professionals to Determine and Prevent Accounting Errors and Frauds: Edirne Sample. Emerging Markets Journal (EMAJ), Vol. 7, No: 1, 53-64.

Akman, V., Acar, B., Kızıl, C. (2020). Audit Techniques to Avoid Cost Accounting Frauds. Emerging Markets Journal (EMAJ), Vol. 10, No: 1, 6066.

Aksoy, T. and Uzay, Ş. (2021). Relationship between Fraud Auditing and Forensic Accounting. In: Aksoy, T., Hacioğlu U. (eds.). Auditing Ecosystem and Strategic Accounting in the Digital Era. Contributions to Finance and Accounting. Springer, Cham. https://doi.org/10.1007/978-3-030-72628-7_6

Aslan, T., Kız1l, C., Din, A. (2017). Muhasebe Hata ve Hileleri Üzerinde Etkili Faktörlerin Muhasebe Meslek Etiği Kapsamında Analizi: Yalova Örneği. Journal of Social and Humanities Sciences Research (JSHSR), Vol. 4, No: 12, 1125-1138,

http://www.jshsr.org/DergiPdfDetay.aspx?ID= 191

Atmaca, M. (2012). Muhasebe Skandallarının Önlenmesinde İç Kontrol Sisteminin Etkinleştirilmesi. Afyon Kocatepe Üniversitesi, İ̈BF Dergisi. Cilt: 14, Say1: 1, 191-205.

Bayraktar, A. (2007). Türkiye'de Muhasebe Hileleri Tarihi. Trakya Üniversitesi Sosyal Bilimler Enstitüsü İşletme Anabilim Dalı Yüksek Lisans Tezi, Edirne.

Bozkurt, N. (2000). İşletmlerde Hile Yapan Çalışanların Karakteristik Özellikleri. Yaklaşım Dergisi. Say1: 93, 57-62.

Bozkurt, N.(2009). İşletmelerin Kara Deliği Hile. Alfa Yayınları. İstanbul.
Bulca, H. V. (2014). Bağımsız Denetim Standartlarının Muhasebede Hile Kavramına Yaklaşımı. Optimum Ekonomi ve Yönetim Bilimleri Dergisi, 1(2), 47-58.

Çubukçu, S. (2009). Muhasebe Hilelerini Ortaya Çıkarmada Benford Modeli. Muhasebe Bilim Dünyası Dergisi. Cilt: 11, Sayı: 3, 113-142.

Dönmez, A., Çavuşoğlu, K.. (2015). Hilelerin Ortaya Çıkarılması Bakımından Bağımsız Denetim ile Adli Muhasebenin Karşılaştırılması. Journal of Accounting, Finance and Auditing Studies (JAFAS). 1(3), 34-67.

Emir, M. (2008). Hile Denetimi. Mali Çözüm Dergisi. $86,109-121$.

Erdoğan, M. (2006). Denetim / Kavramsal ve Teknolojik Yapı. Maliye ve Hukuk Yayınları, Ankara.

Güredin, E. (2007). Denetim ve Güvence Hizmetleri. Arıkan Basım Yayım, İstanbul.

Jamil, A.H., Mohd Sanusi, Z., Yaacob, N.M., Mat Isa, Y. and Tarjo, T. (2021). The Covid-19 impact on financial crime and regulatory compliance in Malaysia. Journal of Financial Crime, Vol. ahead-of-print No. ahead-of-print. https://doi.org/10.1108/JFC-05-2021-0107.

Kandemir, C. (2010). Muhasebe Hilelerinin Ortaya Çıkarılmasında ve Önlenmesinde Bağımsız Denetimin Rolü ve Bağımsız Denetçinin Sorumluluğu. Çukurova Üniversitesi Sosyal Bilimler Enstitüsü Doktora Tezi, Adana.

Kara, M. (2012). Muhasebe Hataları. Muhasebe ve Vergi Denetiminde Muhasebe Hata ve Hileleri kitabı içerisinde. Ekin Basım Yayın Dağıtım, Bursa.

Karausta ve Dönmez. (2013). Mesleki Hile ve Bir Çözüm Önerisi Olarak Adli Denetim: Türkiye'de SPK'dan Yetki Almıș Denetim Firmalarına Yönelik Bir Araştırma. Mali Çözüm Dergisi. 115, 59-88.

Kaval, H. (2005). Muhasebe Denetimi. Gazi Kitabevi, Ankara.

Kızıl, C., Çelik, İ. E., Akman, V., Şener, S. (2016). Yaratıcı Muhasebe Yöntemleri ve Finansal Bilgilerin Manipülasyonu: Profesyonel Muhasebe Meslek Mensupları Üzerinde Örnek Bir Uygulama. Beykent Üniversitesi Sosyal Bilimler Dergisi, Cilt: 9, Say1: 1, 1-18, http://dergipark.ulakbim.gov.tr/bujss/article/do wnload/5000145590/5000161141

Kızıl, C., Kaşbaşı, B. (2018). Accounting Scandals and Eye-Catching Frauds: USA-Japan Comparison by Considering the Role of Auditing. Journal of Asian Research (JAR), Vol. 2, No: 3, pp.123-138, http://dx.doi.org/10.22158/jar.v2n3p123 
Kızıl, C., Muzır, E., Akman, V. (2021). Covid 19 Epidemic: A New Arena of Financial Fraud?. Karabagh International Congress of Modern Studies in Social and Human Sciences, June 17-19, Karabagh, Azerbaijan, 310-314.

Kiracı, M. (2013). Hileye Yönelik Uluslararası Kuruluşlarin Hazırladığı Raporların Bağımsız Denetim Açısından Değerlendirilmesi. Muhasebe ve Vergi Uygulamaları Dergisi, Cilt: 6, Sayı: 3, 87-106.

Kula, V. (2008). Hileli Finansal Raporlama Yaklaşımlarını Belirleyen Teşvikler/Baskılar ve Fırsatlar. Muhasebe ve Denetime Bakış Dergisi, 8, 63-82.

Morales, J., Gendron, Y. and Guenin-Paracini, H. (2014). The Construction of the Risky Individual and Vigilant Organization: A Genealogy of the Fraud Triangle. Accounting, Organizations and Society. Vol. 39, Issue: 3, 170-194.

Özer, M. (1998). Vergisel ve Teknik Boyutuyla Muhasebe. Özkan Matbaacılık, Ankara.

Pazarçeviren, S. (2005). Adli Muhasebecilik Mesleği. Zonguldak Karaelmas Üniversitesi Sosyal Bilimler Dergisi. 1(2), 1-19.

PWC. (2007). The Global Economic Crime Surveys. PWC Website. https://www.pwc.com.tr/tr/advisory09/fraud/as sets/Forensic_Services_tr.pdf (Retrieved on 12.07.2021)

Ramos, M. (2003). Auditors' Responsibility for Fraud Detection. Journal of Accountancy. Website of Journal of Accountancy. https://www.journalofaccountancy.com/issues/ 2003/

jan/auditorsresponsibilityforfrauddetection.htm 1 (Retrieved on 13.07.2021).

Söyler, H. (2013). İşletme Çalışanları Tarafindan Yapılan Hileler. Alomaliye Websitesi. http://www.alomaliye.com/halil_soyler_isletm elerde_yap_hileler_2.htm (Retrieved on 14.07.2021).

Şengür, E. D. (2011). İşletmelerde Hile, Hilelerin Önlenmesi, Hileli Finansal Raporlama ile ilgili Düzenlemeler ve bir Araştırma. İstanbul Üniversitesi Sosyal Bilimler Enstitüsü Doktora Tezi, İstanbul.

Terzi, S. (2012). Hile ve Usulsüzlüklerin Tespitinde Veri Madenciliğinin Kullanimi. Muhasebe ve Finansman Dergisi, Say1: 54, 51-64.

Widiyati, D., Valdiansyah, R. H., Meidijati, M., Hendra, H. (2021). The Role of Public Accountants in Fraud Preventation and Detection in the Taxation Sector during Covid-19. Golden Ratio of Auditing Research, 1(2), 70-82. 